\title{
Article \\ The Origin and Physico-Chemical Properties of Some Unusual Earth Rock Fragments
}

\author{
Alexandru Cocean ${ }^{1}$, Cristina Postolachi ${ }^{1}$, Georgiana Cocean ${ }^{1,2}$, Georgiana Bulai ${ }^{3} \oplus$, \\ Bogdanel Silvestru Munteanu ${ }^{1}$, Nicanor Cimpoesu ${ }^{1,4}$, Iuliana Cocean ${ }^{1}$ and Silviu Gurlui ${ }^{1, *(1)}$
}

1 Faculty of Physics, Alexandru Ioan Cuza University of Iasi, 11 Carol I Bld., 700506 Iasi, Romania; alexcocean@yahoo.com (A.C.); tina.postolaki@gmail.com (C.P.); cocean.georgiana@yahoo.com (G.C.); muntb@uaic.ro (B.S.M.); nicanor.cimpoesu@tuiasi.ro (N.C.); iulianacocean@hotmail.com (I.C.)

2 Rehabilitation Hospital Borsa, 1 Floare de Colt Street, 435200 Borsa, Romania

3 Integrated Center of Environmental Science Studies in the North-Eastern Development Region (CERNESIM), Department of Exact and Natural Sciences, Institute of Interdisciplinary Research, Alexandru Ioan Cuza University of Iasi, 700506 Iasi, Romania; georgiana.bulai@uaic.ro

4 Faculty of Material Science and Engineering, Gheorghe Asachi Technical University of Iasi, 59A Mangeron Bld., 700050 Iasi, Romania

* Correspondence: sgurlui@uaic.ro

Citation: Cocean, A.; Postolachi, C.; Cocean, G.; Bulai, G.; Munteanu, B.S.; Cimpoesu, N.; Cocean, I.; Gurlui, S. The Origin and Physico-Chemical Properties of Some Unusual Earth Rock Fragments. Appl. Sci. 2022, 12, 983. https://doi.org/10.3390/ app12030983

Academic Editor: Fabrizio Balsamo

Received: 26 November 2021

Accepted: 12 January 2022

Published: 19 January 2022

Publisher's Note: MDPI stays neutral with regard to jurisdictional claims in published maps and institutional affiliations.

Copyright: (C) 2022 by the authors. Licensee MDPI, Basel, Switzerland. This article is an open access article distributed under the terms and conditions of the Creative Commons Attribution (CC BY) license (https:// creativecommons.org/licenses/by/ $4.0 /)$.

\begin{abstract}
In this paper, several researches were undertaken related to a violent phenomenon, characterized by a sonic boom, felt on an area of at least $500 \mathrm{~km}^{2}$, shortly followed by the fall of rock fragments that were then recovered from the ground. These presented different appearance characteristics from those of the materials and rocks specific to the respective area. Spectroscopic and petrographic analyses were performed to identify the composition, morphological and crystallinity characteristics in order to elucidate the nature of the collected rock samples. Using FTIR spectroscopy functional groups, as those reported in the literature for Murchison, Bells and Allende, carbonaceous chondrite meteorites were identified. The fragments evidenced topography and morphology that can be assigned to the chondrules and chondrites of carbonaceous meteorites (CMs). The material in the fragments proved to be as insoluble organic material (IOM), being insoluble in water and organic solvents. Its crystalline structure was also evidenced by XRD analysis and FTIR spectrum. These physico-chemical properties, in relation to the sonic boom perceived in the area from where they were collected, indicate the spatial origin of the fragments of rock as possible meteorite fragments.
\end{abstract}

Keywords: chemical and petrographic fingerprint; carbonaceous chondrite; meteorites; LIBS; volatile meteorites; crystallinity

\section{Introduction}

Meteorites are an invaluable source of information about both extraterrestrial bodies and the matter in their composition, as well as physico-chemical interactions that take place in extreme conditions, clearly different from those on earth. The study of meteorites also seeks answers related to the origin of organic matter and life on Earth. Among the categories of meteorites identified so far, that of carbonaceous chondrites is a study material of great interest, with researchers suggesting that, by establishing the connection with the parent body and identifying the physico-chemical phenomena associated with the synthesis of materials, the origin of life can be deciphered [1,2]. In a broader sense, it is about trying to explain the evolution of organic matter and its formation [2-5]. The weathering of carbonaceous chondrite (CC) meteorites by liquid water has also been studied [1,6]. From the category of representative CC meteorites, the Murchison, Bell and Allende meteorites, in which the content of organic material was highlighted by FTIR, SEM-EDS and XRD techniques and classical analytical values (such as density and solubility) [4,7-11], were intensively studied. The methods to detect traces of elements in meteorites, such as 
thorium, have been set up during [12] the use of neutron activation analysis. The content of uranium and thorium in chondrite meteorites (CMs) was also studied by Lovering and Morgan in 1979, by the same neutron activation method [13]. The primitive carbonaceous chondrite, Acfer 094, was analyzed using synchrotron radiation-based X-ray computed nanotomography for a good preservation of the material [14]. In 2014, Coulson et al. [15] proved in a simulation model that fragile types of meteorites, i.e., volatile meteorites, may survive at low altitudes due to their protective outgassing sheath of volatile ices and organic material that protect the meteorite from direct atmospheric heating during its fall. The Maribo carbonaceous chondrite meteorite that fell in 2009 in Denmark, contained organic components very similar to the Murchison meteorite, but also specific characteristics, such as components rich in nitrogen as well as trapped noble gases [16].

The most significant carbon content was identified in IDPs (interplanetary dust particles) with $45 \mathrm{wt} \%$ and in UCAMMs (ultra-carbonaceous Antarctic micrometeorites), the latter containing the highest amounts of organic compounds, up to $90 \mathrm{wt} \%$ [17-19].

This work aims to identify the chemical composition, topography, morphology and crystallinity of two space fragments of rocks that fell to the ground as a result of a large supersonic boom. In order to elucidate the origin of the analyzed pieces, the results were compared with those reported for the carbonaceous chondrite meteorites. The analyses showed similarities with the meteorites presented in the literature, but also certain particularities of special importance. If some of the characteristics are common to a category of meteorites from the same parental body, there are also individual "traits" that have formed under particular conditions and interactions. Thus, an individual profile of the space rock fragments was established based on these particularities and which constitute their chemical and petrographic fingerprint similar to genetic for living beings.

\section{Materials and Methods}

On May 2020, a large sonic boom was felt in Iasi County, with a large number of people confirming this. The press and social networks were the active means of immediate communication of the unusual phenomenon. Two rock fragments that fell from space immediately after that sonic boom were recovered from the Ipate area of Iasi County (Figure 1).

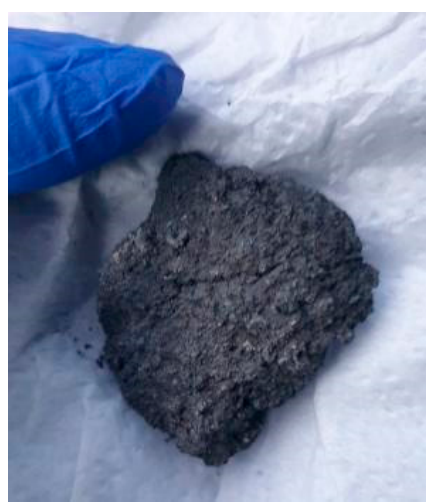

(a)



(b)

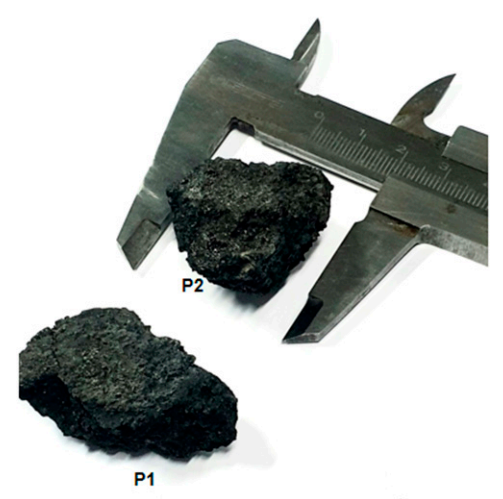

(c)

Figure 1. The two fragments of space rocks found in Ipate (Iasi county of Romania). (a) P1 fragment; (b) P2 fragment and (c) P1 and P2 fragments with a measuring device.

The fragments were brought to our laboratory and subjected to analyses and investigations that would establish their chemical composition and other characteristics, based on which the comparison with meteorites reported by the literature can be made.

The material was first collected from the two fragments of rock, namely sample P1 and sample P2, and was investigated using optical microscopy, Fourier transform infrared spectroscopy (FTIR), scanning electron microscopy (SEM) coupled with energydispersive X-ray spectroscopy (EDS) and X-ray diffraction (XRD) methods. Pieces of about 
3-5 mm edges size were removed from different sides of each of the fragments, P1 and P2, respectively. The pieces of material were first observed by optical microscopy. The resulting pieces of material were then crushed, creating grains of about $0.1-0.2 \mathrm{~mm}$ size. The chemical composition was studied with a Versatile FT-IR Laboratory Spectrometer MB3000 used on dry powder samples. For the FTIR analysis, about $10 \mathrm{mg}$ of crushed material from each of the fragments, P1 and P2, was finely ground. From the resulting fine powders, about $1 \mathrm{mg}$ of each sample was incorporated into about $200 \mathrm{mg}$ of potassium bromide $(\mathrm{KBr})$ used as suspension media, and compressed into a stainless steel ring under $100 \mathrm{~atm}$ of pressure, as per the method described by Cocean et al. Appl. Sci., 2021 [20]. In the SEM-EDS investigation with Bruker AXS Microanalysis $\mathrm{GmbH}$, both the bulk material of about 3-5 mm edges size (from sample P1) and about $200 \mathrm{mg}$ of powder from both samples, P1 and P2, was analyzed. The crystalline structure of the powders resulting from the crushing of the material of each of the two fragments was analyzed by $\mathrm{X}$-ray diffraction using a Shimadzu LabX XRD-6000 Diffractometer with a Cu K $\alpha$ radiation $(\lambda=1.54 \AA$ ). About $200 \mathrm{mg}$ of crushed material of each of the samples, P1 and P2, was used for analysis by the XRD technique. The diffraction patterns were recorded in the $10^{\circ}-80^{\circ} 2 \theta$ range with a $2 \mathrm{deg} / \mathrm{min}$ scanning speed.

The dissolution was tested in water and in ethanol $90 \%$, with the maximum exposure time of the samples of powder from the fragments of rock being two months in glass tubes with a stopper, so that the liquid did not evaporate. For each test, $2 \mathrm{mg}$ of crushed material of each sample was used in $1 \mathrm{~mL}$ of liquid.

The rock fragments were then wrapped in food foil and immersed in water to determine their volume. For this purpose, a graduated glass vessel filled with water was used. To determine the mass, the analytical balance with 3 decimals was used. The density was further calculated based on the measured volume and mass.

\section{Results and Discussions}

\subsection{Solubility and Density}

When trying to dissolve the sample of the material, it was found that the dissolution did not take place, not even partially; the two phases (the water and solid granules in the sample) did not mix, and the particles were only dispersed by stirring. The water remained clear at all times. The result was the same in the alcohol, in which the granules of the samples also did not dissolve. Insoluble organic matter (IOM) has been reported in the case of the Murchison meteorite, in which the highest proportion of organic carbon is similar to that of kerosene (similar to terrestrial kerogen). An elemental formula has been established for the Murchison meteorite $\mathrm{C}_{100} \mathrm{H}_{46} \mathrm{~N}_{10} \mathrm{O}_{15} \mathrm{~S}_{4.5}$, being a material with a complex composition, but which is not fully elucidated at the molecular level. [8]. After a period of several weeks, the agglomeration of the particles in the water and those in the alcohol was observed, in a formation with a structure similar to that of the initial sample. This may be due to fullerenes, but also to other special structural features of the constituent materials. Additionally, the tendency of the particles to aggregate in the liquid (as observed during the dissolution test) shows the role of water and ethyl alcohol in this regard.

An explanation of the aggregation phenomenon could be given by the formation of hydrogen bonds or Van der Waal interactions in the presence of hydroxyl ions, but also in the conditions of partial dissolution (dissolution of carbonates, sulfates and other metal salts). Furthermore, the dissolution of soluble compounds, such as metal salts, can have the effect of a phenomenon of the complexation of metal ions with insoluble organic compounds, resulting in the aggregation of molecules according to the pattern of precipitation and flocculation.

The density of the sample material was calculated based on the measurements of the volume and mass as it states in Table 1. 
Table 1. Volume, mass and density of the two fragments of space rocks.

\begin{tabular}{ccccccc}
\hline Sample & $\begin{array}{c}\mathbf{V T} \\
{[\mathbf{m L}]}\end{array}$ & $\begin{array}{c}\mathrm{VH}_{\mathbf{2}} \mathbf{O} \\
{[\mathbf{m L}]}\end{array}$ & $\begin{array}{c}\mathbf{V P}=\mathbf{V T}-\mathbf{V H}_{\mathbf{2}} \mathbf{O} \\
{[\mathbf{m L}]}\end{array}$ & $\begin{array}{c}\mathbf{M} \\
{[\mathbf{g}]}\end{array}$ & $\begin{array}{c}\rho=\mathbf{M} / \mathbf{V P} \\
{\left[\mathbf{g} / \mathbf{c m}^{3}\right]}\end{array}$ & $\begin{array}{c}\mathbf{V T} \\
{[\mathbf{m L}]}\end{array}$ \\
\hline $\mathrm{P} 1$ & 53.08 & 40 & 13.08 & 13.573 & 1.037 & 70 \\
\hline $\mathrm{P} 2$ & 70 & 46.16 & 23.84 & 20.30 & 0.851 & 0.535 \\
\hline $\begin{array}{c}\rho_{\mathrm{av}}=\rho_{1} / \rho_{2} \\
{\left[\mathrm{~g} / \mathrm{cm}^{3}\right]}\end{array}$ & & & & 0.944 & \\
\hline
\end{tabular}

\subsection{FTIR Spectra Analysis}

FTIR spectra analysis (Figure 2) was performed on material collected from the two samples (P1 and P2) presumed as being meteoritic material. The vibrational bands of the two spectra were compared with those obtained for the Murchison and Bells meteorites [7] and the results are presented in Table 2.

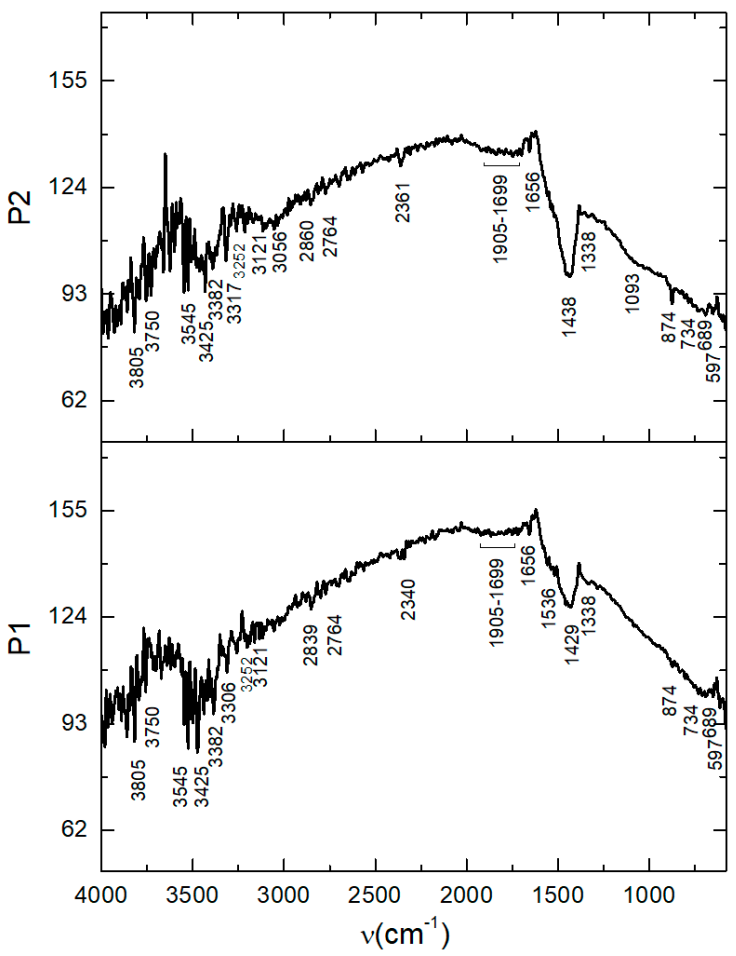

(a)

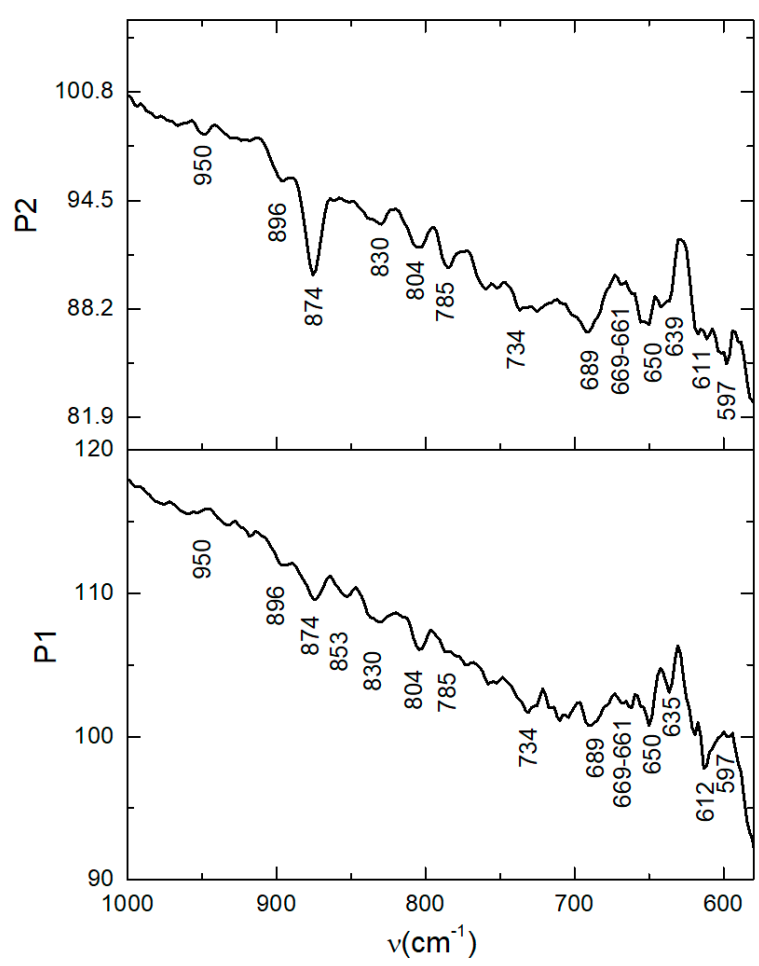

(b)

Figure 2. FTIR spectra of the material extracted from the two fragments of rocks: (a) in the wavenumber range of 4000 to $580 \mathrm{~cm}^{-1}$ and (b) zoom on the wavenumber range of 1000 to $580 \mathrm{~cm}^{-1}$.

Table 2. Compared FTIR spectra of the samples and the Murchison and Bells meteorites ( ${ }^{*}$ Vibration modes that are not reported for Murchison, Allende and Bells Meteorites.)

\footnotetext{
Vibration Bands in the

Sample Spectra $\left[\mathrm{cm}^{-1}\right]$
}

P1 P2 
Table 2. Cont.

\begin{tabular}{|c|c|c|c|}
\hline \multicolumn{2}{|c|}{$\begin{array}{l}\text { Vibration Bands in the } \\
\text { Sample Spectra }\left[\mathrm{cm}^{-1}\right]\end{array}$} & \multirow[t]{2}{*}{ Functional Groups } & \multirow{2}{*}{ In Meteorites } \\
\hline P1 & P2 & & \\
\hline $\begin{array}{c}3750 \\
(\text { sharp })\end{array}$ & $\begin{array}{c}3750 \\
\text { (doublet) }\end{array}$ & $\begin{array}{l}\text { - Terminal groups of silanol Si-OH bond to a polymer } \\
\text { chain }[21,22]\end{array}$ & * \\
\hline 3545 & $\begin{array}{c}3545 \\
\text { (doublet) }\end{array}$ & $\begin{array}{l}\text { - } \mathrm{O}-\mathrm{H} \text { stretching, free (not H-bonded), from adsorbed } \\
\text { water bounded [21] }\end{array}$ & * \\
\hline 3425 & 3425 & $\begin{array}{l}\text { - OH groups, free or H-bonded denote water } \\
\text { molecules, but also COOH [21] } \\
\text { - } \quad \text { Possible amino groups (N-H) }\end{array}$ & $\begin{array}{l}\text { Murchison Meteorite: } \sim 3400 \text { and } \\
1640 \mathrm{~cm}^{-1} \text {, and are assigned to } \\
\text { structural and/or absorbed } \mathrm{H}_{2} \mathrm{O} \text { of } \\
\text { hydrous silicates } \\
\text { Bells Meteorite: } 3400 \mathrm{~cm}^{-1} \\
\text { corresponding to } \mathrm{OH}[7]\end{array}$ \\
\hline 3382 & 3382 & $\begin{array}{l}\text { - OH groups specific to carboxylic acids (in the } \mathrm{COOH} \\
\text { group) [21] } \\
\text { - } \quad \text { Possible amino groups }(\mathrm{N}-\mathrm{H})\end{array}$ & * \\
\hline $3306 ; 3252$ & $3317 ; 3252$ & $\begin{array}{l}\text { - OH groups specific to carboxylic acids (in the } \mathrm{COOH} \\
\text { group) [21] }\end{array}$ & * \\
\hline 3121 & 3121 & - $\quad$ Chelated structures in $\mathrm{CaCO}_{3}[21,23]$ & * \\
\hline * & 3056 & - $\quad($ ar)C-C groups specific to aromatic compounds [21] & * \\
\hline
\end{tabular}

Murchison Meteorite: 2960, 2930, and $2860 \mathrm{~cm}^{-1}$; assigned to the aliphatic $\mathrm{C}-\mathrm{H}$ stretching modes

- $\mathrm{C}-\mathrm{H}$ in aliphatic compounds [21]

- $\quad$ Parent fullerene stretching bonds for $\mathrm{C}_{60} \mathrm{H}_{36.27}$ [24].

Bells Meteorite: $2950 \mathrm{~cm}^{-1}$ assigned to aliphatic C-H [7]

Fullerenes identified in Murchison and Allende carbonaceous chondrite meteorites [9];

Fullerenes identified in Murchison and

$2764 \quad$ - $2764 \quad$ Parent fullerene stretching bonds for $\mathrm{C}_{60} \mathrm{H}_{36.27}$ [24]. Allende carbonaceous chondrite meteorites [9]

$2340 \quad-\quad$ Adsorbed $\mathrm{CO}_{2}[25]$

* * *

Murchison Meteorite: $1730 \mathrm{~cm}^{-1}$ corresponding to $\mathrm{C}=\mathrm{O}$

Bells Meteorite: $\sim 1730 \mathrm{~cm}^{-1}$ assigned to $\mathrm{C}=\mathrm{O}[7]$

\begin{tabular}{|c|c|c|}
\hline 1905-1699 & 1905-1699 & $\begin{array}{l}\text { - Stretching vibrations of } \mathrm{C}-\mathrm{O} \text { bonds in } \mathrm{COOH}[21] \\
\text { - } \\
\text { band) meta di-substitution }\left(864 \mathrm{~cm}^{-1} \text { band }\right)\end{array}$ \\
\hline 1656 & 1656 & $\begin{array}{l}\text { O-H group in absorbed molecules of water and/or } \\
\text { structural molecules of water of hydrous silicates [7 } \\
\text { Stretching vibration modes of } \mathrm{C}=\mathrm{O} \text { involved in } \\
\text { hydrogen bonds in amides, as well as amino group } \\
\text { (N-H), assigned to } \mathrm{NHC}=\mathrm{O} \text { amides I free and } \\
\text { H-bonded [21,26]. } \\
\text { - In the same range, } \mathrm{C}=\mathrm{C} \text { stretching modes in arenes }\end{array}$ \\
\hline
\end{tabular}

Murchison Meteorite: at $\sim 3400$ and $1640 \mathrm{~cm}^{-1}$, and are assigned to structural and/or absorbed $\mathrm{H}_{2} \mathrm{O}$ of hydrous silicates [7] 
Table 2. Cont.

\begin{tabular}{|c|c|c|c|}
\hline \multicolumn{2}{|c|}{$\begin{array}{l}\text { Vibration Bands in the } \\
\text { Sample Spectra }\left[\mathrm{cm}^{-1}\right]\end{array}$} & \multirow[t]{2}{*}{ Functional Groups } & \multirow[t]{2}{*}{ In Meteorites } \\
\hline P1 & P2 & & \\
\hline 1656 & 1656 & $\begin{array}{l}\text { O-H group in absorbed molecules of water and/or } \\
\text { structural molecules of water of hydrous silicates [7] } \\
\text { Stretching vibration modes of } \mathrm{C}=\mathrm{O} \text { involved in } \\
\text { hydrogen bonds in amides, as well as amino groups } \\
(\mathrm{N}-\mathrm{H}) \text {, assigned to } \mathrm{NHC}=\mathrm{O} \text { amides I free and } \\
\text { H-bonded [21,26]. } \\
\text { In the same range, } \mathrm{C}=\mathrm{C} \text { stretching modes in arenes }\end{array}$ & $\begin{array}{l}\text { Murchison Meteorite: at } \sim 3400 \text { and } \\
1640 \mathrm{~cm}^{-1} \text {, and are assigned to } \\
\text { structural and/or absorbed } \mathrm{H}_{2} \mathrm{O} \text { of } \\
\text { hydrous silicates [7] }\end{array}$ \\
\hline 1536 & * & $\begin{array}{l}\text { - } \quad \text { Skeletal vibrations of aromatic bonds } \mathrm{C}=\mathrm{C}[21] \\
\text { - } \\
\text { - }\end{array}$ & 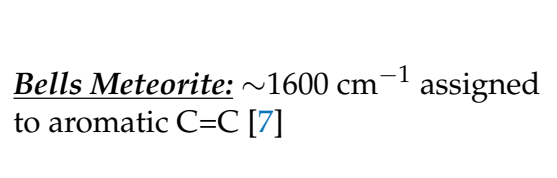 \\
\hline 1429 & 1438 & $\begin{array}{ll}- & \mathrm{CO}_{3}^{2-}\left(\text { in } \mathrm{CaCO}_{3}\right)[23] \\
- & \text { Crystalline structure [27-29] } \\
\text { - } & \mathrm{C} 60 \text { in fullerenes [30] }\end{array}$ & $\begin{array}{l}\text { Murchison Meteorite: around } \\
1435 \mathrm{~cm}^{-1} ; \text { assigned to } \mathrm{CO}_{3}^{2-} \\
\text { of carbonates } \\
\text { Bells Meteorite: } 1450 \mathrm{~cm}^{-1} \text { assigned to } \\
\text { carbonates [7] } \\
1453 \text { [30] } \\
\mathrm{CH}_{2} \text { deformation mode in } \\
\mathrm{CH}_{2}-\mathrm{C}=\mathrm{C}[20]\end{array}$ \\
\hline * & 1093 & $\begin{array}{ll}\text { - } & \mathrm{C}-\mathrm{O} \text { in carboxylic acids }\left(\sim 1100 \mathrm{~cm}^{-1}\right) \text { [21] } \\
\text { - } & \text { in fullerenes }\left(1050 \mathrm{~cm}^{-1}\right)[24] \\
\text { - } & \mathrm{SO}_{4}^{2-} \text { in FeSO }\left(1090 \mathrm{~cm}^{-1}\right)[23] \\
\text { - } & \mathrm{Si}-\mathrm{O}-\mathrm{Si} \text { stretching [21] }\end{array}$ & $\begin{array}{l}\text { Murchison Meteorite: } 1150 \mathrm{~cm}^{-1} \\
\text { assigned to } \mathrm{SO}_{4}^{2-} \text { of sulfates } \\
\text { Bells Meteorite: } 1124 \mathrm{~cm}^{-1} \\
\text { corresponding to sulfates [7] }\end{array}$ \\
\hline $\begin{array}{c}950 \\
853 ; 804\end{array}$ & $\begin{array}{c}950 \\
830 ; 804\end{array}$ & $\begin{array}{l}\text { - } \quad \text { Si-O stretching }[7,21] \\
\text { - } \\
\text { (bot- }\left(\mathrm{CH}_{3}\right)_{2} \text { skeletal vibration and } \mathrm{Si}-\mathrm{O}-\mathrm{C} \text { stretching } \\
\text { (both in the same range of } \sim 850 ; \sim 800) \text { [21] }\end{array}$ & $\begin{array}{l}\text { Murchison Meteorite: around } \\
1000 \mathrm{~cm}^{-1} \text {, assigned to the } \mathrm{Si}-\mathrm{O} \\
\text { stretching modes of silicates } \\
\text { Bells Meteorite: silicate peaks at } \\
\text { around } 1000 \mathrm{~cm}^{-1} ; 1010 \mathrm{~cm}^{-1} \\
\text { corresponding to } \mathrm{SiO}[7]\end{array}$ \\
\hline 874 & 874 & $\begin{array}{l}\text { - } \quad \text { Carbonate ions } \mathrm{CO}_{3}{ }^{2-} \text { with bending modes out of } \\
\text { plane }[23,28,29,31] \\
\text { - } \quad \text { Skeletal vibrations } \mathrm{C}-\mathrm{O}[21,29]\end{array}$ & * \\
\hline $\begin{array}{l}(900-650) \\
734\end{array}$ & $\begin{array}{l}(900-650) \\
734\end{array}$ & - $\quad$ Th-O and Th (IV) [32] & * \\
\hline 650 & 650 & - $\quad$ S-O stretching vibrations in $\mathrm{CaSO}_{3}$ [25] & * \\
\hline $669 ; 661$ & $669 ; 661$ & - $\quad$ S-O stretching vibrations in $\mathrm{CaSO}_{4}$ [25] & * \\
\hline $\begin{array}{c}(874-689) \\
689\end{array}$ & $\begin{array}{l}(874-689) \\
689\end{array}$ & - $\quad$ S-O stretching in sulfites [21] & * \\
\hline 689 & 689 & $\begin{array}{l}\text { - } \quad \mathrm{C}-\mathrm{H} \text { aromatic bending out of plane modes [21] } \\
\text { - } \quad \text { In the same range, adsorbed molecular } \mathrm{CO}_{2}[25]\end{array}$ & * \\
\hline 612 & 611 & - $\quad$ S-O stretching vibrations in $\mathrm{FeSO}_{4}$ [25] & * \\
\hline 597 & 597 & $\begin{array}{ll}\text { - } & \text { C60 in fullerenes [30] } \\
\text { - } & \text { stretching modes of C-Si [21] }\end{array}$ & * \\
\hline
\end{tabular}


The summary of the evidenced chemical compounds in the FTIR spectra (Figure 2) is as follows:

$>$ Carboxylic acids and/or amino acids (also in the Murchison and Bells carbonaceous chondrite meteorites);

$>$ Amines, amides I and II;

$>$ Aliphatic (also in the Murchison and Bells carbonaceous chondrite meteorites) and aromatic compounds (also in the Bells carbonaceous chondrite meteorite);

$>$ Fullerenes (also in the Allende carbonaceous chondrite meteorite);

$>$ Carbonates (also in the Murchison and Bells carbonaceous chondrite meteorites) as calcium carbonate in a crystalline state = calcite (the strong peak at 1429 and $1438 \mathrm{~cm}^{-1}$;

$>$ Sulfates (also in the Murchison and Bells carbonaceous chondrite meteorites) as calcium sulfate $\left(\mathrm{CaSO}_{4}\right.$ and $\left.\mathrm{FeSO}_{4}\right)$ and sulfites as calcium sulfite $\left(\mathrm{CaSO}_{3}\right)$;

$>$ Thorium oxides (Th IV);

$>$ Silicates (also in the Murchison and Bells carbonaceous chondrite meteorites) and silanol groups $(\mathrm{Si}-\mathrm{OH})$ as terminal groups bonded to the polymeric chain;

$>$ Adsorbed water free molecules and H-bonded (also in the Murchison and Bells carbonaceous chondrite meteorites);

$>$ Absorbed and structural water in hydrous silicates (also in the Murchison and Bells carbonaceous chondrite meteorites);

$>$ Adsorbed carbon dioxide $\left(\mathrm{CO}_{2}\right)$ on the fragments' surface;

$>$ Sulfur may also be included in the organic compounds as sulfones and sulfoxides;

$>$ The shape of the baseline of the two FTIR spectra that drops off at both edges indicates a scattering effect, due to crystalline structures. (See the bands at $1429 \mathrm{~cm}^{-1}$ in P1 and at $1438 \mathrm{~cm}^{-1}$ in P2). The shift of the peak between the two samples is due to the influence of the other two crystalline components in sample $\mathrm{P} 1\left(\mathrm{SiO}_{2}-\right.$ moganite and $\mathrm{CaSO}_{4}$-anhydrite) to the specific vibration of crystalline $\mathrm{CaCO}$, compared with sample $\mathrm{P} 2$ where only crystalline $\mathrm{CaCO}_{3}$ (calcite) was detected by XRD.

Absorbed water on the surface of the material is evidenced in both $\mathrm{P} 1$ and $\mathrm{P} 2$ by the bands at $3805 \mathrm{~cm}^{-1}$ (P1), $3545 \mathrm{~cm}^{-1}(\mathrm{P} 1, \mathrm{P} 2)$, denoting free $\mathrm{O}-\mathrm{H}$ groups and $3425 \mathrm{~cm}^{-1}$ $(\mathrm{P} 1, \mathrm{P} 2)$ assigned to $\mathrm{O}-\mathrm{H}$ groups that can be free or hydrogen bounded $[20,21]$. Noisy spectra denote $\mathrm{H}_{2} \mathrm{O}$ absorbed into the analyzed samples or hydrated compounds. The water absorbed into the meteoritic material or adsorbed onto the surface of the fragment or of the pores is in accordance with Coulson et al. [15], who consider the meteorite as a "coherent carbonaceous matrix with pores filled with water ice and volatile organics". Kebukawa et al. [7] reported bands at $\sim 3400 \mathrm{~cm}^{-1}$ for the Murchison and Bells FTIR spectra assigned to $\mathrm{H}_{2} \mathrm{O}$ absorbed of the hydrous silicates. The band at $3805 \mathrm{~cm}^{-1}$ may also indicate silanol groups (Si-OH) [21]. Vibrations at $3750 \mathrm{~cm}^{-1}$ (P1, P2), known as specific to silanol bonding to a polymer chain [22], confirmed the $\mathrm{Si}-\mathrm{OH}$ groups. Chemical structures with silicon are also denoted by the vibrational band at $950 \mathrm{~cm}^{-1}$, which is assigned to $\mathrm{Si}-\mathrm{O}$ stretching $[7,20,21]$ and the bands at $853 \mathrm{~cm}^{-1}$ and $804 \mathrm{~cm}^{-1}$ are assigned to $\mathrm{Si}-\left(\mathrm{CH}_{3}\right)_{2}$ skeletal vibration and $\mathrm{Si}-\mathrm{O}-\mathrm{C}$ stretching, both in the same range of $~ 850 ; ~ 800$ [21].

Vibrational bands at $3382 \mathrm{~cm}^{-1}$ (P1, P2), $3306 \mathrm{~cm}^{-1}$ (P1) and $3317 \mathrm{~cm}^{-1}$ (P2) and $3252 \mathrm{~cm}^{-1}$ (P1, P2), indicate the $\mathrm{OH}$ groups specific to carboxylic acids in the $\mathrm{COOH}$ functional group, but also the possible amino groups $(\mathrm{N}-\mathrm{H})$ [21] denoting possible amino acids. The large band in the range of $1905 \mathrm{~cm}^{-1}-1699 \mathrm{~cm}^{-1}$ (P1, P2) is assigned to carbonyl groups, but also to the stretching vibrations of the bonds $\mathrm{C}-\mathrm{O}$ in the group $\mathrm{COOH}$ of carboxylic acids [21]. The bond $\mathrm{C}-\mathrm{O}$ was also confirmed by the band at $1093 \mathrm{~cm}^{-1}(\mathrm{P} 2)$, as well as the $864 \mathrm{~cm}^{-1}$ band (P2) [21]. In the same range of $1905 \mathrm{~cm}^{-1}-1699 \mathrm{~cm}^{-1}$, the arenes overtones due to mono-substitution (coupled with the $689 \mathrm{~cm}^{-1}$ band) and meta di-substitution (coupled with the $864 \mathrm{~cm}^{-1}$ band) were also identified. Aromatic compounds are denoted in the P2 FTIR spectrum by the $3056 \mathrm{~cm}^{-1}$ band (P2) specific to (ar)C-C groups [21] and the $1536 \mathrm{~cm}^{-1}$ band specific to the skeletal vibrations of the aromatic bonds, $\mathrm{C}=\mathrm{C}$, reported in literature as being in the range of $1610 \mathrm{~cm}^{-1}-1550 \mathrm{~cm}^{-1}$ (P1) [21]. In the spectrum of the 
Bells meteorite, the vibrations specific to aromatic $C=C$ were found at about $1600 \mathrm{~cm}^{-1}$ [7]. The sample P1 spectrum also indicated amides II, NHC=O free and $\mathrm{H}$-bonded (in the same range with $\mathrm{C}=\mathrm{C}$ aromatic) [21].

The chelated structures are indicated by the bands at $3121 \mathrm{~cm}^{-1}(\mathrm{P} 1, \mathrm{P} 2)$ and are assigned to calcium carbonate, $\mathrm{CaCO}_{3}$, and the vibrations specific to $\mathrm{CO}_{3}{ }^{2-}$ at $1429 \mathrm{~cm}^{-1}$ (P1) and $1438 \mathrm{~cm}^{-1}$ (P2) [31] are also present in the FTIR spectra of the two samples. Kebukawa et al. [7] reported bands assigned to carbonates at $1435 \mathrm{~cm}^{-1}$ and $1450 \mathrm{~cm}^{-1}$ in the Murchison and Bells meteorite spectrum, respectively. The symmetric stretch modes of the carbonate ions $\mathrm{CO}_{3}{ }^{2-}$ at $1093 \mathrm{~cm}^{-1}$ (P2) and $874 \mathrm{~cm}^{-1}$ (P1, P2) out-of-plane bending modes $[22,27,28,30]$ complete the information provided by the FTIR spectrum of the P2 sample, regarding the content in carbonates.

The strong peaks at $1429 \mathrm{~cm}^{-1}(\mathrm{P} 1)$ and $1438 \mathrm{~cm}^{-1}$ (P2) also denote the crystalline state due to calcium carbonate in the samples of the materials.

The band at $1656 \mathrm{~cm}^{-1}$ in both the P1 and P2 FTIR spectra are assigned to the O-H group of absorbed water in hydrous silicates - as also reported by Kebukawa et al. [7] for the Murchison meteorite. Correlating this with the multiple bands from $3805 \mathrm{~cm}^{-1}, 3750 \mathrm{~cm}^{-1}$ and $3545 \mathrm{~cm}^{-1}$, the first two may indicate the silanol groups in polymeric structures or even additional to fullerenes. In the same range $\left(1656 \mathrm{~cm}^{-1}\right)$ there are stretching vibration modes specific to carbonyl groups $\mathrm{C}=\mathrm{O}$ involved in hydrogen bonds [21]. This would indicate amides; hence, amino groups $(\mathrm{N}-\mathrm{H})$ are also in the same vibrations range [25] assigned to amides $\mathrm{I}, \mathrm{NHC}=\mathrm{O}$, free or $\mathrm{H}$-bonded [21]. In the same range, $\mathrm{C}=\mathrm{C}$ stretching modes in arenes are reported in the literature [21].

Aliphatic C-H is identified in the bands at $2839 \mathrm{~cm}^{-1}(\mathrm{P} 1)$ and $2860 \mathrm{~cm}^{-1}$ (P2) [20]. Kebukawa et al. [7] reported stretching modes assigned to aliphatic C-H at 2960, 2930 and $2860 \mathrm{~cm}^{-1}$ for the Murchison meteorite and $2950 \mathrm{~cm}^{-1}$ for the Bells meteorite.

In the same range, the bands at $2839 \mathrm{~cm}^{-1}, 2764 \mathrm{~cm}^{-1}(\mathrm{P} 1), 2860 \mathrm{~cm}^{-1}$ and $2764 \mathrm{~cm}^{-1}$ (P2) denote the fullerene structures of the $\mathrm{C}_{60} \mathrm{H}_{36.27}$ type [24]. $\mathrm{C}_{60}$ in the fullerenes is also indicated by the bands at $1430 \mathrm{~cm}^{-1}$ and $597 \mathrm{~cm}^{-1}$ [30] in both samples (P1, P2); in the same range, the $C-$ Si stretching modes are assigned in the literature [21]. The band at $1093 \mathrm{~cm}^{-1}$ could also be assigned to $\mathrm{C}-\mathrm{O}$ stretching in the fullerenes [24] as skeletal vibrations due to C-O stretching [21]. Parent fullerene has been previously identified in the meteorites [9].

The band at $1093 \mathrm{~cm}^{-1}$ denotes the sulfates and sulfites, $\mathrm{SO}_{4}{ }^{2-}$ and $\mathrm{SO}_{3}{ }^{2-}$, in $\mathrm{CuSO}_{4}$, $\mathrm{CaSO}_{4}, \mathrm{CaSO}_{3}$ and in $\mathrm{FeSO}_{4}$. Based on the elemental composition determined by EDS analysis, the $1093 \mathrm{~cm}^{-1}$ is assigned to $\mathrm{CaSO}_{4}, \mathrm{CaSO}_{3}$ and to $\mathrm{FeSO}_{4}$. This assignment also takes into account the $\mathrm{S}-\mathrm{O}$ stretching vibrations that $\mathrm{CaSO}_{4}$ exhibits at $667 \mathrm{~cm}^{-1}$ and that are noticed in the P1 spectrum $\left(669 ; 661 \mathrm{~cm}^{-1}\right)$ and less intensely in the P2 spectrum $\left(669 ; 661 \mathrm{~cm}^{-1}\right)$ and that $\mathrm{FeSO}_{4}$ exhibits at $611 \mathrm{~cm}^{-1}$, which is noticed in the P1 spectrum $\left(611 \mathrm{~cm}^{-1}\right)$ and P2 spectrum $\left(612 \mathrm{~cm}^{-1}\right)$ [25]. The band at $650 \mathrm{~cm}^{-1}$ is assigned to S-O stretching in calcium sulfite $\mathrm{CaSO}_{3}$ in the P1 and P2 spectra [25] confirming sulfites. Calcium sulfate is also confirmed by the difractogram of XRD analysis. Kebukawa et al. [7] have reported $\mathrm{SO}_{4}{ }^{2-}$ in the Murchison and Bells meteorites.

Vibration modes at $2340 \mathrm{~cm}^{-1}$ (P1) and $2361 \mathrm{~cm}^{-1}$ (P2) and $689 \mathrm{~cm}^{-1}$ (P1, P2) are assigned to molecular adsorbed $\mathrm{CO}_{2}$ [25].

According to Ali et al. [31], the bands in the range of $900-650 \mathrm{~cm}^{-1}$ could be assigned to thorium covalent bonds with oxygen (Th-O and $\mathrm{O}-\mathrm{Th}-\mathrm{O}$ ) [12] also evidenced Thorium in meteorites. It is important to notice that in the FTIR spectra of samples P1 and P2 is the curved base line, which drops off at both the left and right sides, indicating the effects of scattering, possibly due to the crystalline state of the particles analyzed, to the effect of carbon black or to spherical particles. The shape of the baseline may also indicate the biological material (DNA) causing Mie scattering, or the non-Lambert-Beer absorption behavior in biological cells [33].

The FTIR spectra of the two samples (P1, P2) exhibit bands of similar wavenumbers as those reported for the Murchison and Bells meteorites. The spectra of the P1 and P2 samples exhibit fullerene structures that were not reported for the Murchison and Bells meteorites, 
but are reported by Becker et al. [9] as evidence for meteorites. Carbonates, silanol groups and adsorbed $\mathrm{CO}_{2}$ are also identified in the spectra of the P1 and P2 samples. Vibration modes different to what was reported for the Murchison and Bells meteorites complete those already reported by Kebukawa et al. [7], for the aromatic structures. Organic kerogen-like matter, referred to as "Murchison Insoluble Organic Material (IOM)" by Pizzarello et al. [8], is evidenced when corroborating the FTIR spectra with the high insolubility of samples P1 and P2 in water and alcohol, as presented before.

The chemical components identified by FTIR spectroscopy are also confirmed by EDS elemental analysis and $\mathrm{XRD}$, the latter evidencing the crystalline structures of calcium carbonate $\left(\mathrm{CaCO}_{3}, \mathrm{CaSO}_{4}\right.$ and $\left.\mathrm{SiO}_{2}\right)$.

\subsection{Crystallinity Analysis from XRD}

The XRD analysis results in Figure 3, mainly show the crystalline structures of calcites, which is in accordance with the FTIR spectra in which the peaks assigned to $\mathrm{CO}_{3}{ }^{2-}$ and the chelate structure are noticed, including the strong peaks at $1429 \mathrm{~cm}^{-1}$ (sample P1) and $1438 \mathrm{~cm}^{-1}$ (sample P2) specific to $\mathrm{CaCO}_{3}$ in the crystalline state. While the P2 sample presented peaks that correspond to only the calcite phase, $\mathrm{CaCO}_{3}$ hexagonal (reference card ICSD 98-001-8166), the P1 sample presented two additional diffraction lines that were associated with anhydride, $\mathrm{CaSO}_{4}$ orthorhombic (reference card ICSD 98-000-1956) and moganite, $\mathrm{SiO}_{2}$ monoclinic (reference card ICSD 98-006-7669).

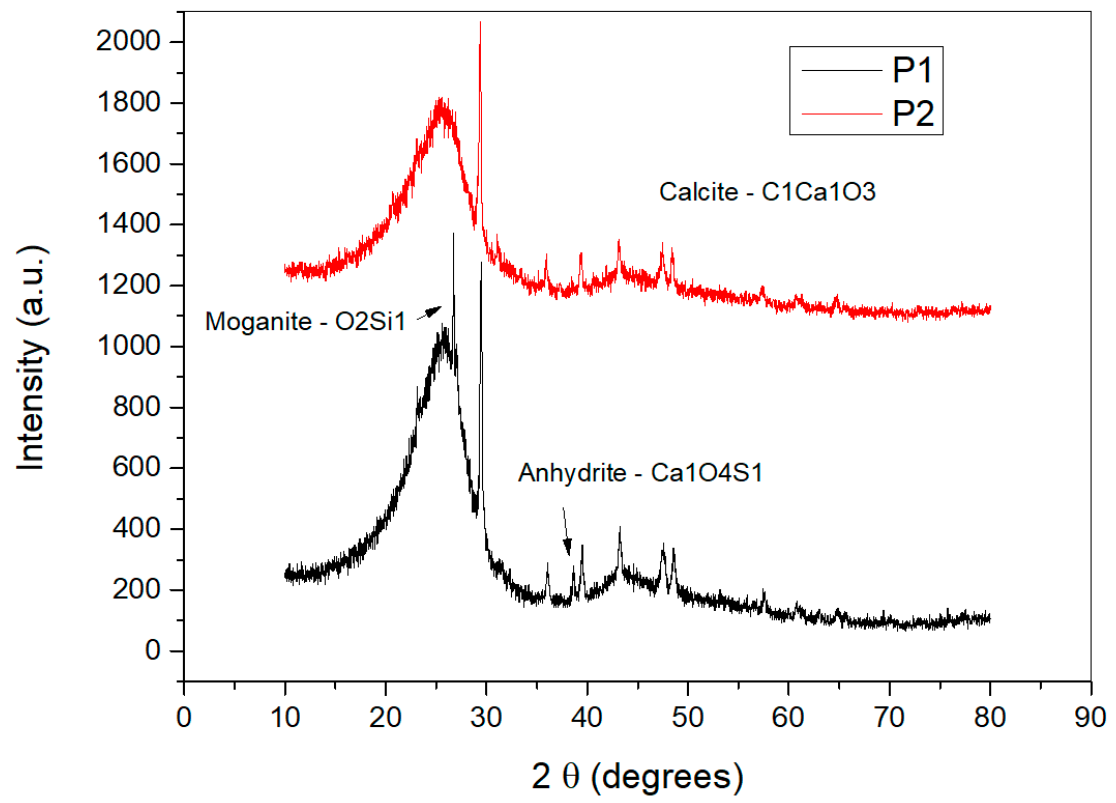

Figure 3. XRD Difractogram.

Calcium carbonate $\left(\mathrm{CaCO}_{3}\right)$ in a crystalline state was identified in the Murray meteorite, but was identified as aragonites $\left(\mathrm{CaCO}_{3}\right.$ orthorhombic) by Lee et al. [6].

\subsection{Elemental Composition Analyzed with Energy Dispersive Spectroscopy (EDS)}

Elemental composition performed with energy dispersive X-ray analysis on different surfaces of the sample, proved the non-homogeneity of the material concerning the atomic percentage, but with the constituting elements dispersed on all the surfaces, except for $\mathrm{Si}$, $\mathrm{Pb}$ and $\mathrm{Mn}$, which are detected only on certain areas of the studied surface. Table 3 reflects the results concerning the percentages of each component element on different surfaces. 
Table 3. EDS analysis results on the elemental composition.

\begin{tabular}{cccc}
\hline \multirow{2}{*}{ Element } & s1 & Atom [\%] & s3 \\
\cline { 2 - 4 } & 85.9724 & $\mathbf{s 2}$ & 80.3783 \\
\hline Carbon & 12.1562 & 20.4560 & 17.0068 \\
\hline Oxygen & 1.4799 & 0.8755 & 0.5528 \\
\hline Sulfur & 0.3714 & 0.4666 & 1.6246 \\
\hline Calcium & $\bullet$ & 0.2580 & 0.2675 \\
\hline Silicon & 0.0025 & 0.0117 & 0.0052 \\
\hline Thorium & 0.0065 & 0.0927 & 0.0823 \\
\hline Magnesium & $\bullet$ & 0.0542 & 0.0398 \\
\hline Aluminum & 0.0045 & 0.0242 & 0.0229 \\
\hline Iron & 0.0066 & 0.0137 & 0.0104 \\
\hline Nickel & $\bullet$ & 0.0009 & $\bullet$ \\
\hline Lead & $\bullet$ & $\bullet$ & 0.0093 \\
\hline Manganese & 100 & 100 & 100 \\
\hline
\end{tabular}

The EDS spectra for the two fragments of rock are presented in Figure 4.

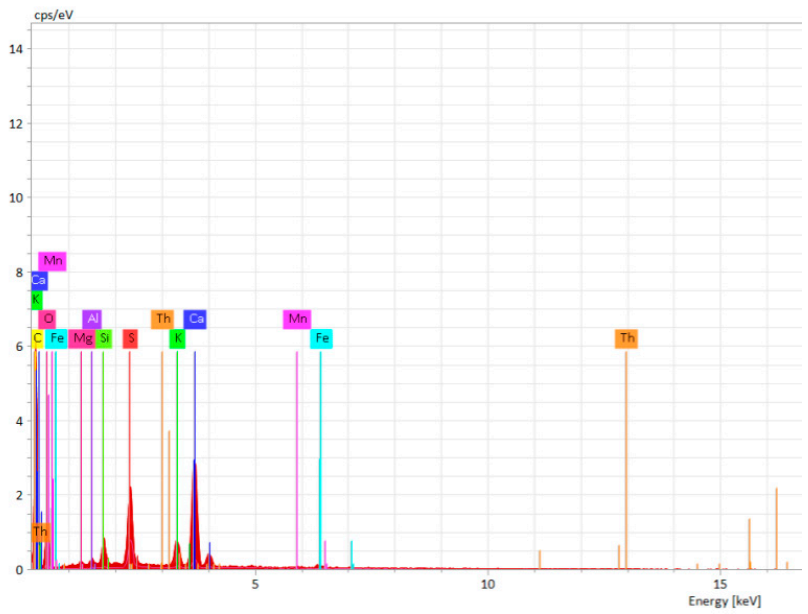

(a)

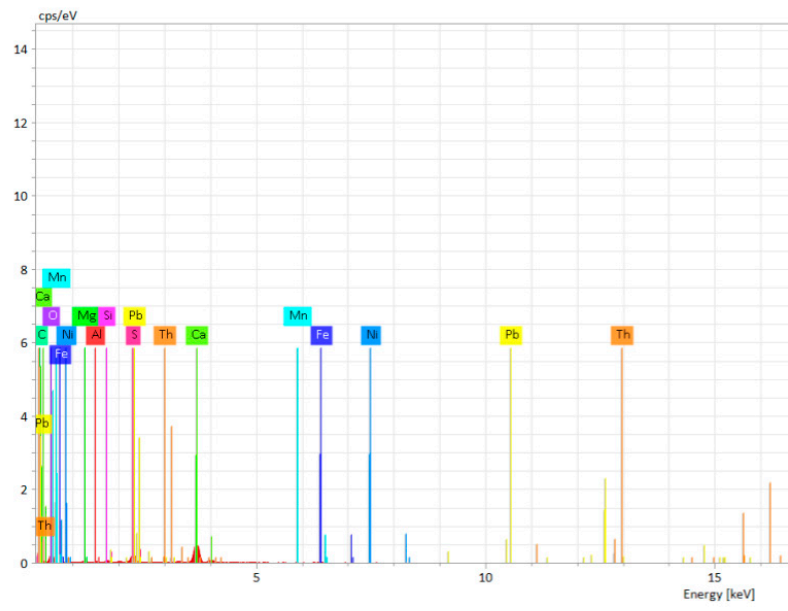

(b)

Figure 4. EDS spectra resulted on the analyzed areas $(\mathbf{a}, \mathbf{b})$, on areas of the samples of rocks S1 (a) and S2 (b).

\subsection{Petrography}

The petrography of the fragments of rocks (P1 and P2) was studied based on optical microscopy and SEM images and maps of elements.

\subsubsection{Optical Microscopy Images}

In the images acquired with the optical microscope (Figure 5), the metallic droplets are evidenced, as well as other structures, such as granular- and needle-shaped structures, that may be assigned to oxides or metal salts. In accordance with the XRD difractogram (Figure 3), granular structures can be assigned to moganite $\left(\mathrm{SiO}_{2}\right)$ and to calcites $\left(\mathrm{CaCO}_{3}\right)$, and the needle-shaped structures belong to anhydride $\left(\mathrm{CaSO}_{4}\right)$. 


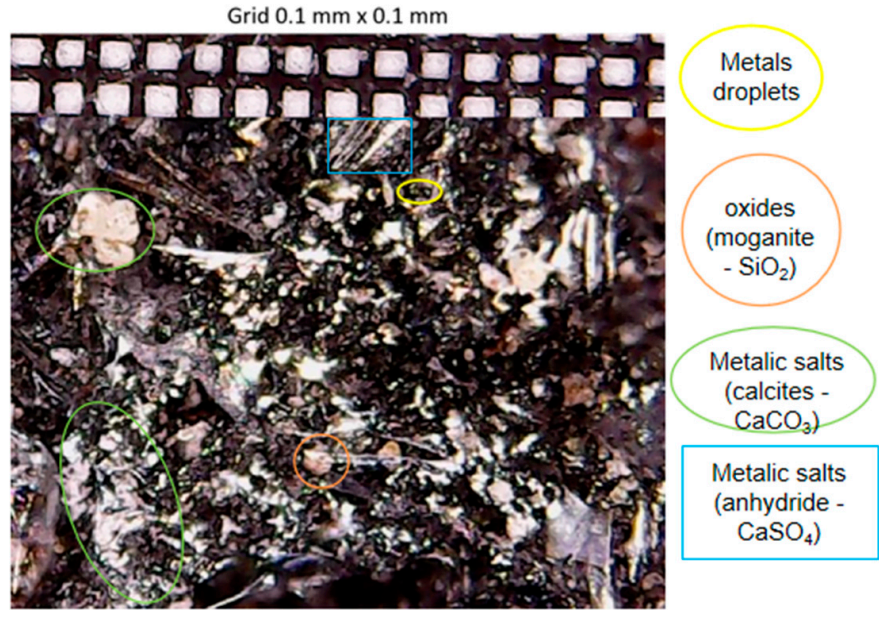

(a)



(b)

Figure 5. Optical microscopy images: (a) P1 sample and (b) P2 sample.

\subsubsection{Surface Morphology Analyzed with Scanning Electron Microscopy (SEM)}

SEM images provide morphological and topographic information on the material of meteorites. Similar structures were evidenced as being reported [10] for carbonaceous chondrites. The grains of chondrules, droplets of metals or metal oxides in the carbonaceous chondrite matrix can be distinguished, as indicated in the SEM images (a)-(f) in Figure 6.

The SEM image shows white grains of different sizes assigned to oxides and the crystalline state, and the veins of a darker and lighter color indicating the relief of the sample. The fullerene individual sheet is identified in Figure 6d [34].

\subsubsection{Maps of Elements}

The maps of the chemical elements (Figure 7) offer an image of the non-homogeneous distribution of the chemical elements, indicating, at the same time, the identity of the components that are also confirmed by FTIR and XRD analyses. In the sense of the abovementioned factors, we further present the mapping analysis and morphological aspect (SEM images) on several areas studied from samples P1 and P2 of the rock fragments.

The maps of the elements of the area denoted as P1m-Ch1, which is part of the P1 fragment in massive state, evidence carbon $(\mathrm{C})$ that can be assigned to organic compounds: sulfur $(S)$ in organics, as sulfones, also the sulfates/sulfites of calcium $\left(\mathrm{CaSO}_{4} / \mathrm{CaSO}_{3}\right)$. Nevertheless, some of the calcium (Ca) in the P1m-Ch1 area may be part of the calcium-aluminum inclusions (CAI), as per the maps of the elements. A grain of a significant size of silicon oxide $\left(\mathrm{SiO}_{2}\right)$ is noticed in the right side of the area, while the silicon in the left side of the area is assigned to $\mathrm{Si-OH}$ as a silanol bond to organics. Iron (Fe), similar to nickel (Ni), is in the finely dispersed particles. The very low percentage of Fe and Ni makes it difficult to estimate if they are part of the Kamacite structures (Fe-Ni). The grains of a more significant size are noticed on the iron map. They can be assigned to iron oxides. It is not excluded that some of the iron is involved in chemical structures, such as troilite (Fe-S) and iron sulfate $\left(\mathrm{FeSO}_{4}\right)$ chondrules.

The area denoted as P1m-Ch2, also part of the P1 fragment in massive state, exhibits on the maps the disposal of the chemical elements indicating carbon $(\mathrm{C})$ assigned to carbonates $\left(\mathrm{CaCO}_{3}\right)$, but also based on the XRD and FTIR analysis, supposed to be in organics or as adsorbed $\mathrm{CO}_{2}$. Sulfur (S) can be assigned to sulfates, but also to organic compounds, such as sulfones, when corroborating the maps with the FTIR and XRD analyses. The area mapping $\mathrm{P} 1 \mathrm{~m}-\mathrm{Ch} 1$ provides evidence of calcium sulfate $\left(\mathrm{CaSO}_{4}\right)$. Other than abovementioned compounds with calcium, the maps of $\mathrm{Ca}$ and $\mathrm{O}$, respectively, also indicate $\mathrm{CaO}$ as well as possible CAI (calcium-aluminum inclusions). 




(a)



(c)

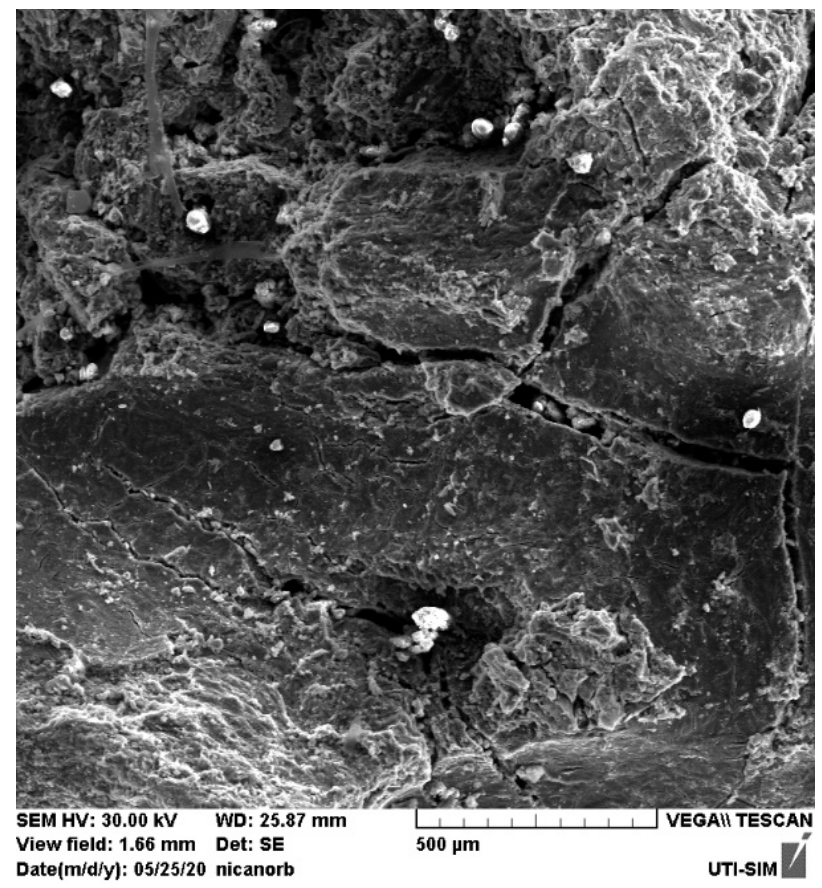

(b)

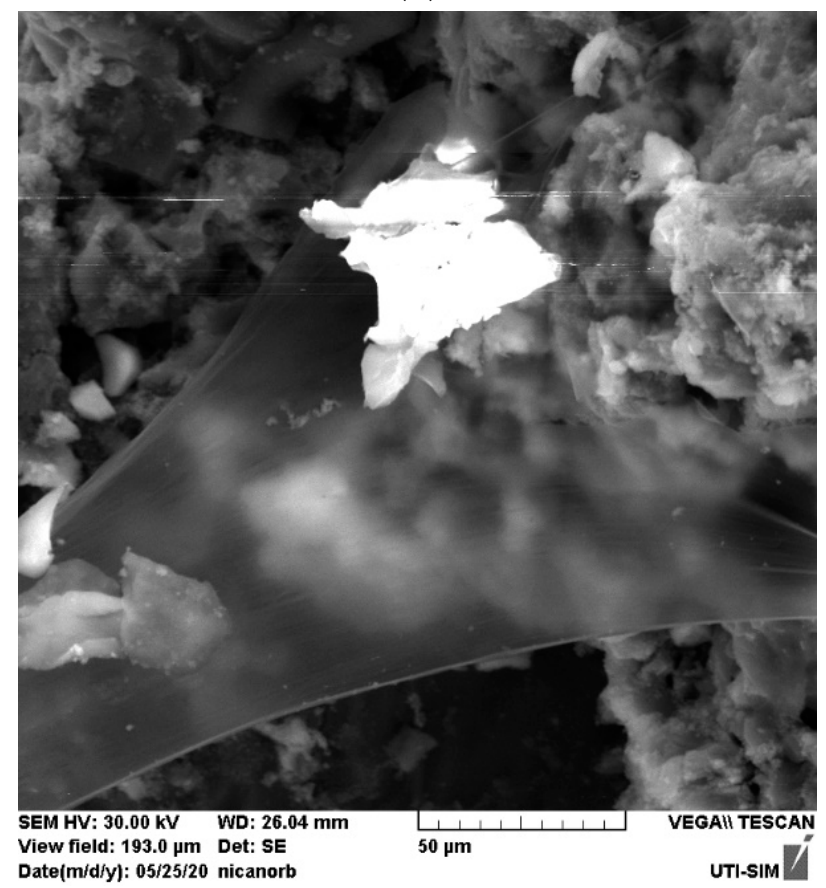

(d)

Figure 6. Cont. 


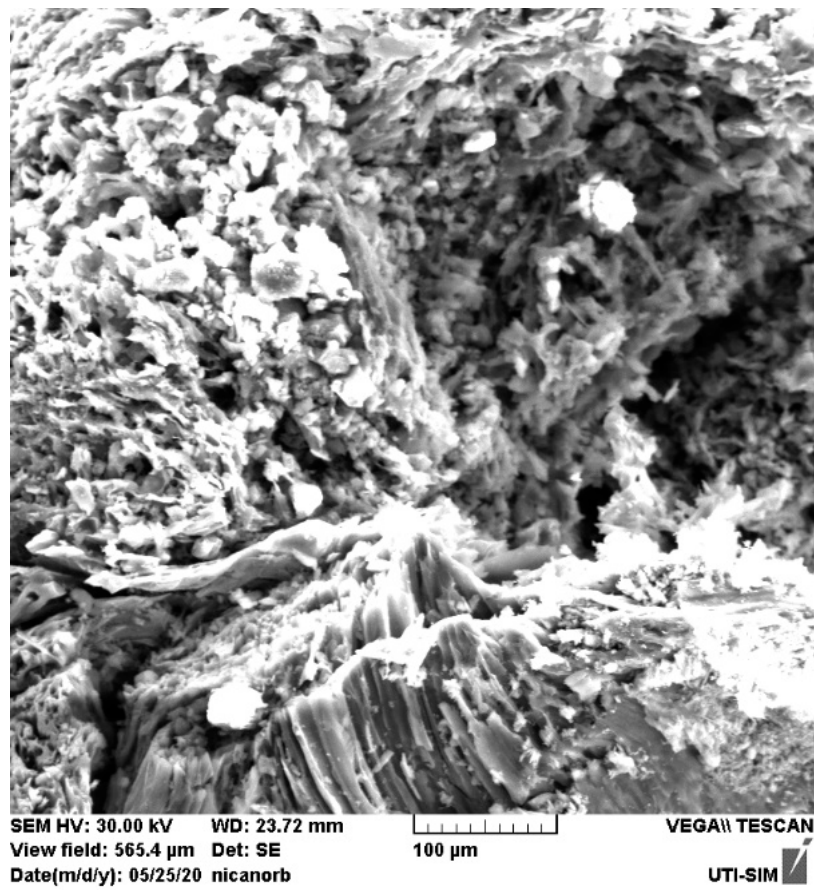

(e)

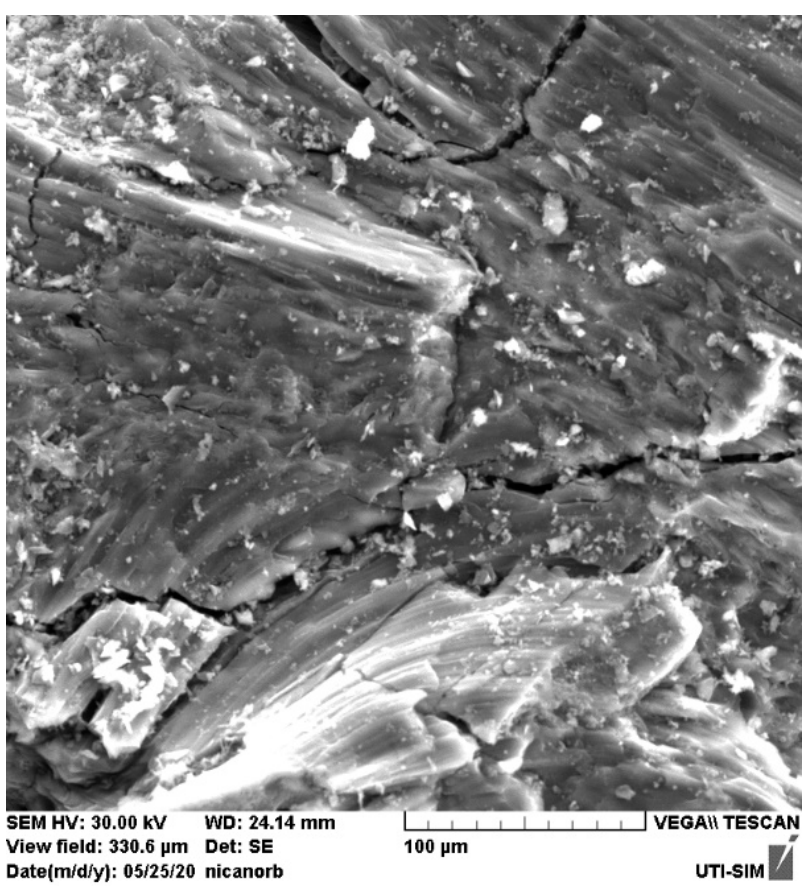

(f)

Figure 6. SEM images of the different areas on the fragments of rock: P1 sample in the (a-d) images adnd $\mathrm{P} 2$ sample in the images $(\mathbf{e}, \mathbf{f})$.

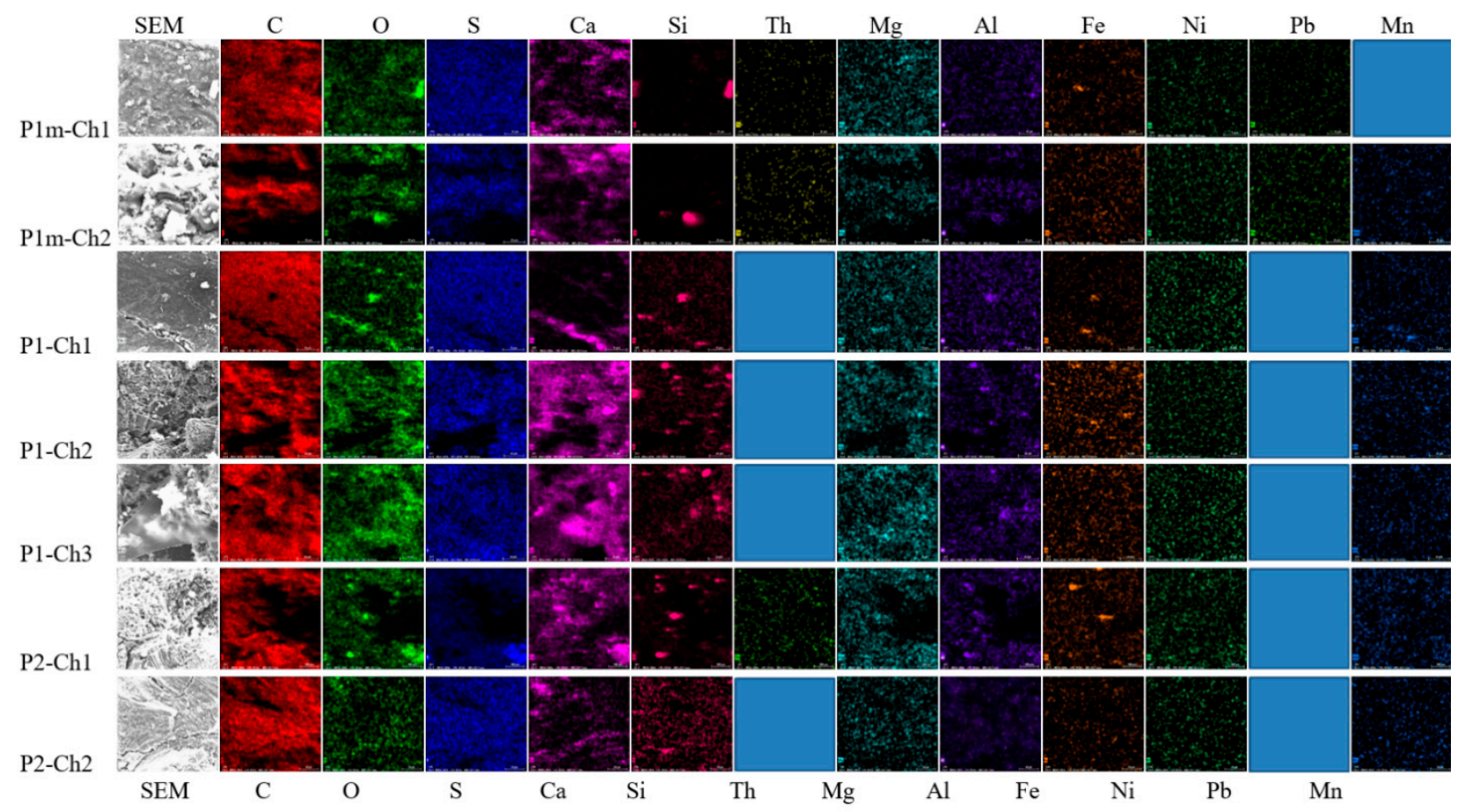

Figure 7. Maps of chemical element distribution on the different studied surfaces.

Thorium (Th) may be assigned as thorium oxides $\left(\mathrm{ThO}_{2}\right)$, as FTIR spectra also indicate (Figure 2). Troilite (Fe-S), lead ( $\mathrm{Pb}$ ) and manganese $(\mathrm{Mn})$ are also noticed. The SEM image of this area of the massive/bulk material of the P1 fragment of rock, shows a high number of large size grains in white color.

The fragments of rock P1 and P2 were also analyzed in a powder state obtained by slight pressing due to their friability. 
The maps of the elements of the P1-Ch1area of P1 powder show carbon assigned to be in organic compounds as sulfones and cloudy-disposed carboxylic acids, while calcium (Ca) as oxide $(\mathrm{CaO})$ is disposed in the veins. Particles of silicon oxide $\left(\mathrm{SiO}_{2}\right)$ were finely dispersed on all the studied surfaces, but also grains of significant sizes were noticed, among which the grain in the center of the studied area of P1-Ch1 denotes aggregation in the chondrules pattern. Due to the very low percentage of $\mathrm{Mg}, \mathrm{Al}$ and $\mathrm{Fe}$, it is difficult to estimate, but the oxides of these elements might be in the area denoted as P1-Ch1. Manganese (Mn) and nickel (Ni) are also noticed. The SEM image of the area shows grains and veins as preserved structures after the fragment of rock was crushed for analysis. This fact confirms the presence of structures with high mechanical resistance, such as a crystal lattice identified by FTIR and XRD analysis. An analysis of the mechanical properties was not made, because the study focused on the chemical composition, the existence of crystalline structures and the arrangement of the compounds in chondrule-shaped agglomerations.

The maps of the elements on a second area of the powder of the P1 sample, denoted as P1-Ch2, shows the arrangement of elements indicating carbonates $\left(\mathrm{CaCO}_{3}\right)$, sulfates (mainly $\mathrm{CaSO}_{4}$, and possibly $\mathrm{MgSO}_{4}, \mathrm{FeSO}_{4}$ and $\mathrm{Al}_{2}\left(\mathrm{SO}_{4}\right)_{3}$ ), carbon in organics, sulfur in organics, a large number of chondrules containing silicon oxide and aluminum $\left(\mathrm{SiO}_{2} / \mathrm{Al}\right)$, as well as a very low content in Fe and $\mathrm{Ni}$. In addition to the granular structures, this area studied at SEM on the P1 fragment powder shows porous structures associated with carbon (according to mapping), which is part of the organic type IOM (insoluble organic material), or fullerene C60. In fact, a transparent strand of what is identified as a fullerene individual sheet is seen at the bottom of the image [34].

A third area of P1 powder sample, identified as P1-Ch3, is denoted by the maps of element content of sulfates $\left(\mathrm{CaSO}_{4}\right)$ and calcium oxide $(\mathrm{CaO})$, as well as some calcium carbonate $\left(\mathrm{CaCO}_{3}\right)$ in a crystalline state. The calcium carbonate in the calcite grains may be assigned to Tochilinite due to the content in sulfur evidenced in the same area. Transparent sheet observed in the SEM image is assigned to individual fullerene sheets, fullerene C60 being evidenced by the FTIR spectra (Figure 2) similar to graphene transparent sheets, evidenced by Khenfouch et al. [34], on the SEM images of synthesized graphene fewlayered sheets. The carbon in the organics with sulfur is also observed on the maps of elements of the P1-Ch3 area of the sample. Grains of chondrules with $\mathrm{SiO}_{2}$ in a crystalline state are evidenced in CAIs. Finely dispersed silicon may be assigned to phyllosilicates organized in parallel sheets as $\left[\mathrm{Si}_{2} \mathrm{O}_{52}-\right]$. Finely dispersed Fe-Ni and $\mathrm{Mn}$ particles are also observed.

On the maps of the P2-Ch1 area of the powder sample from fragment P2, the elements calcium $(\mathrm{Ca})$, carbon $(\mathrm{C})$, oxygen $(\mathrm{O})$ and sulfur are assigned to oxide, carbonate and sulfate $\left(\mathrm{CaO}_{2}, \mathrm{CaCO}_{3}\right.$ and $\left.\mathrm{CaSO}_{4}\right)$. Calcium is also assigned to CAIs and carbon is also assigned to organics with sulfur (sulfones). Grains of $\mathrm{SiO}_{2}$ metallic iron (Fe) chondrules, and also finely dispersed Fe-Ni particles, are noticed. Thorium (Th) is assigned to thorium oxides. The SEM image of this area shows the structures with good mechanical strength, practically those structures, such as chondrules.

The second studied area on the powder sample of fragment P2, denoted as P2-Ch2, shows, based on the maps of elements corroborated with the FTIR spectrum, carbon (C) in organic compounds and organic compounds with sulfur. The veins of calcium carbonate $\left(\mathrm{CaCO}_{3}\right)$ and grains of $\mathrm{CaCO}_{3}$ assigned to calcites in tochilinite, due to sulfur observed, are evidenced by the maps of the elements. However, it is obvious that sulfur areas overlap the carbon areas in an almost identical pattern, indicating that the majority of the sulfur is an organic bond. Chondrules with a content of silicon oxide $\left(\mathrm{SiO}_{2}\right)$, magnesium $(\mathrm{Mg})$, aluminum (Al), manganese (Mn) and Fe-Ni particles are observed by element arrangements in the maps. The SEM image of this area shows less brittle carbon structures than the material as a whole, but with a tendency to crack following the mechanical stress to which it was subjected. 


\section{Conclusions}

There are indications that the samples studied herein are part of a stony type of meteorite, subtype chondrites, class carbonaceous as per classification found in [35,36], which went through a weathering process by liquid water $[1,6]$ with a high content of organic carbon, mainly IOM (insoluble organic matter) of the kerogen-type, but also fullerene. Absorbed, carbon dioxide enhances the percentage of the carbon element determined by EDS analysis. An explanation for the high content in carbon may be the accumulation of IDPs. Detected water molecules by FTIR analysis are assigned to the remnant water of a volatile ice sheath that used to protect the meteorite from direct atmospheric heating. Thus, the fragments may be part of the category of volatile meteorites, as described in the model of dynamics of volatile meteorites presented by Coulson et al. [15]. The metals in oxides, carbonate and sulfate, but also being possible to enter in coordination with organic substances, complete the image of the chemical composition of the fragments. Petrographic analysis provides information on the elements dispersion within the material, but also the aggregation in the chondrules type of particles or structured in veins. By comparing the results obtained with the analyses of some meteorites long studied in the literature, the similarities of composition and structure were found. The specific fingerprint of the material in the two fragments is given by the high carbon content, as well as by the friability of the bulk material compared to the hardness of the particles that result from crushing it. The bulk friability can be considered to be caused by the loss of volatile organic compounds and/or water, which has led to the weakening of the bonds between the particles. The tendency of the particles to aggregate in the liquid (as observed during the dissolution test), shows the role of water and ethyl alcohol in this regard. Although it can be attributed to the partial dissolution and formation of hydrogen bonds, Van der Waals interactions and/or coordination and complexation bonds, this phenomenon requires in-depth studies to establish the exact nature of the connections that lead to the aggregation phenomenon.

Author Contributions: Conceptualization, S.G. and I.C.; methodology, A.C., I.C., G.C. and S.G.; investigation, C.P., G.B., B.S.M. and N.C.; writing-original draft preparation, I.C. and S.G.; writing-review and editing, S.G.; supervision, S.G. All authors have read and agreed to the published version of the manuscript.

Funding: This research was funded by the Ministry of Research, Innovation and Digitization, project FAIR_09/24.11.2020 and by the Executive Agency for Higher Education, Research, Development and Innovation, UEFISCDI, ROBIM, project number PN-III-P4-ID-PCE2020-0332 and the Operational Program Competitiveness 2014-2020, Axis 1, under POC/448/1/1, research infrastructure projects for public R\&D institutions/Sections F 2018, through the Research Center with Integrated Techniques for Atmospheric Aerosol Investigation in Romania (RECENT AIR) project, under grant agreement MySMIS no. 127324.

Acknowledgments: The authors would like to thank Ciprian Ifteme from Ipatele (Iasi) for his help in recovering these fragments.

Conflicts of Interest: The authors declare no conflict of interest.

\section{References}

1. Hyman, H.; Fegley, B.; Prinn, R.G.; Lewis, J.S. Carbonaceous chondrites and the origin of life. LPI Contrib. 1982, 497, 36. [CrossRef]

2. Callahan, M.P.; Smith, K.E.; Cleaves II, H.J.; Ruzickad, J.; Sterna, C.J.; Glavina, D.P.; House, C.H.; Dworkina, J.P. Carbonaceous meteorites contain a wide range of extraterrestrial nucleobases. Proc. Natl. Acad. Sci. USA 2011, 108, 13995-13998. [CrossRef] [PubMed]

3. Glavin, D.P.; Alexander, C.M.D.; Aponte, J.C.; Dworkin, J.P.; Elsila, J.E.; Yabuta, H. The Origin and Evolution of Organic Matter in Carbonaceous Chondrites and Links to Their Parent Bodies. In Primitive Meteorites and Asteroids; Abreu, N., Ed.; Elsevier: Amsterdam, The Netherlands, 2018; pp. 205-271. [CrossRef]

4. Sephton, M.A. Organic matter in ancient meteorites. Astron. Geophys. 2004, 45, 2.8-2.14. [CrossRef]

5. Endreß, M.; Bischoff, A. Carbonates in CI chondrites: Clues to parent body evolution. Geochim. Cosmochim. Acta 1996, 60, 489-507. [CrossRef]

6. Lee, M.R.; Ellen, R. Aragonite in the Murray (CM2) carbonaceous chondrite: Implications for parent body compaction and aqueous alteration. Meteorit. Planet. Sci. 2008, 43, 1219-1231. [CrossRef] 
7. Kebukawa, Y.; Kobayashi, H.; Urayama, N.; Baden, N.; Kondo, M.; Zolensky, M.E.; Kobayashi, K. Nanoscale infrared imaging analysis of carbonaceous chondrites to understand organic-mineral interactions during aqueous alteration. Proc. Natl. Acad. Sci. USA 2019, 116, 753-758. [CrossRef] [PubMed]

8. Pizzarello, S.; Shock, E. The Organic Composition of Carbonaceous Meteorites: The Evolutionary Story Ahead of Biochemistry. Cold Spring Harb. Perspect. Biol. 2010, 2, a002105. [CrossRef] [PubMed]

9. Becker, L.; Poreda, R.J.; Nuth, J.A.; Ferguson, F.T.; Liang, F.; Billups, W.E. Fullerenes in Meteorites and the Nature of Planetary Atmospheres. In Natural Fullerenes and Related Structures of Elemental Carbon. Developments in Fullerene Science; Rietmeijer, F.J.M., Ed.; Springer: Berlin/Heidelberg, Germany, 2006. [CrossRef]

10. Guaita, C. SEM exploration of carbonaceus chondrites. Mem. Della Soc. Astron. Ital. Suppl. 2012, $20,74$.

11. Kööp, L.; Heck, P.R.; Busemann, H.; Davis, A.M.; Greer, J.; Maden, C.; Meier, M.M.M.; Wieler, R. High early solar activity inferred from helium and neon excesses in the oldest meteorite inclusions. Nat. Astron. 2018, 2, 709-713. [CrossRef]

12. Bate, L.; Huizenga, J.R.; Potratz, H.A. Thorium in stone meteorites by neutron activation analysis. Geochim. Cosmochim. Acta 1959, 16, 88-100. [CrossRef]

13. Lovering, J.F.; Morgan, J.W. Uranium and thorium abundances in stony meteorites: 1. The chondritic meteorites. J. Geophys. Res. 1964, 69, 1979-1988. [CrossRef]

14. Matsumoto, M.; Tsuchiyama, A.; Nakato, A.; Matsuno, J.; Miyake, A.; Kataoka, A.; Ito, M.; Tomioka, N.; Kodama, Y.; Uesugi, K.; et al. Discovery of fossil asteroidal ice in primitive meteorite Acfer 094. Sci. Adv. 2019, 5, eaax5078. [CrossRef]

15. Coulson, S.G.; Wallis, M.K.; Wickramasinghe, N.C. On the dynamics of volatile meteorites. Mon. Not. R. Astron. Soc. 2014, 445, 3669-3673. [CrossRef]

16. Haack, H.; Grau, T.; Bischoff, A.; Horstmann, M.; Wasson, J.; Sørensen, A.; Laubenstein, M.; Ott, U.; Palme, H.; Gellissen, M.; et al. Maribo-A new CM fall from Denmark. Meteorit. Planet. Sci. 2011, 47, 30-50. [CrossRef]

17. Martins, Z.; Chan, Q.H.S.; Bonal, L.; King, A.; Yabuta, H. Organic Matter in the Solar System-Implications for Future on-Site and Sample Return Missions. Space Sci. Rev. 2020, 216, 54. [CrossRef]

18. Bradley, J.P. Early Solar Nebula Grains-Interplanetary Dust Particles. In Treatise on Geochemistry, 2nd ed.; Holland, H.D., Turekian, K.K., Eds.; Elsevier: Amsterdam, The Netherlands, 2014; pp. 287-308.

19. Dartois, E.; Engrand, C.; Duprat, J.; Godard, M.; Charon, E.; Delauche, L.; Sandt, C.; Borondics, F. Dome C ultracarbonaceous Antarctic micrometeorites Infrared and Raman Õngerprints. Astron. Astrophys. 2018, 609, A65. [CrossRef]

20. Cocean, A.; Cocean, I.; Cimpoesu, N.; Cocean, G.; Cimpoesu, R.; Postolachi, C.; Popescu, V.; Gurlui, S. Laser Induced Method to Produce Curcuminoid-Silanol Thin Films for Transdermal Patches Using Irradiation of Turmeric Target. Appl. Sci. 2021, 11, 4030. [CrossRef]

21. Pretch, E.; Bülmann, P.; Badertscher, M. Structure Determination of Organic Compounds, 4th ed.; Springer: Berlin/Heidelberg, Germany, 2009. [CrossRef]

22. van den Boom, A.F.J.; Pujari, S.P.; Bannani, F.; Driss, H.; Zuilhof, H. Fast room-temperature functionalization of silicon nanoparticles using alkyl silanols. Faraday Discuss. 2020, 222, 82-94. [CrossRef] [PubMed]

23. Miller, F.A.; Wilkins, C.H. Infrared Spectra and Characteristic Frequencies of Inorganic Ions. Their Use in Qualitative Analysis. Anal. Chem. 1952, 24, 1253-1294. [CrossRef]

24. Wu, H.J.; Goodwin, D.G., Jr.; Peter, K.; Benoit, D.; Li, W.; Fairbrother, D.H.; Fortner, J.D. Photo-Oxidation of Hydrogenated Fullerene (Fullerane) in Water. Environ. Sci. Technol. Lett. 2014, 1, 490-494. [CrossRef]

25. Israel, F.P. Light on Dark Matter; Springer: Berlin/Heidelberg, Germany, 1986.

26. Cocean, I.; Cocean, A.; Postolachi, C.; Pohoata, V.; Cimpoesu, N.; Bulai, G.; Iacomi, F.; Gurlui, S. Alpha keratin amino acids behvior under high fluence laser interaction. Medical applications. Appl. Surf. Sci. 2019, 488, 418-426. [CrossRef]

27. Hospodarova, V.; Singovszka, E.; Stevulova, N. Characterization of Cellulosic Fibers by FTIR Spectroscopy for Their Further Implementation to Building Materials. Am. J. Anal. Chem. 2018, 9, 303-310. [CrossRef]

28. Andersen, F.A.; Brecevic, L. Infrared of amorphous and Crystalline Calcium Carbonate. Acta Chem. Scand. 1991, 45, 1018-1024. [CrossRef]

29. Cai, G.-B.; Chen, S.-F.; Liu, L.; Jiang, J.; Yao, H.-B.; Xu, A.-W.; Yu, S.-H. 1,3-Diamino-2-hydroxypropane-N,N,N',N'N-tetraacetic acid stabilized amorphous calcium carbonate: Nucleation, transformation and crystal growth. CrystEngComm 2010, 12, $234-241$. [CrossRef]

30. Alves, G.C.; Ladeira, L.O.; Righi, A.; Krambrock, K.; Calado, H.D.; Pereira de Freitas Gil, R.; Pinheiro, M.V.B. Synthesis of C60(OH)18-20 in Aqueous Alkaline Solution Under O2-Atmosphere. J. Braz. Chem. Soc. 2006, 17, 1186-1190. [CrossRef]

31. Bőkea, H.; Akkurtb, S.; Ôzdemirb, S.; Gőktürkc, E.H.; Saltikd, E.N.C. Quantification of $\mathrm{CaCO}_{3}-\mathrm{CaSO}_{3} \bullet 0.5 \mathrm{H}_{2} \mathrm{O}-\mathrm{CaSO}_{4} \bullet 2 \mathrm{H}_{2} \mathrm{O}$ mixtures by FTIR analysis and its ANN mode. Mater. Lett. 2004, 58, 723-726. [CrossRef]

32. Ali, M.; Aslani, A.; Celik, F.; Mermer, O.; Aslani, C.K. Assessment of reaction between thorium and polyelectrolyte nano-thin film using Box-Behnken design. Adsorpt. Sci. Technol. 2018, 36, 586-607. [CrossRef]

33. Mohlenhoff, B.; Romeo, M.; Diem, M.; Woody, B.R. Mie-Type Scattering and Non-Beer-Lambert Absorption Behavior of Human Cells in Infrared Microspectroscopy. Biophys. J. Vol. 2005, 88, 3635-3640. [CrossRef] [PubMed] 
34. Khenfouch, M.; Buttner, U.; Baïtoul, M.; Maaza, M. Synthesis and Characterization of Mass Produced High Quality Few Layered, Graphene Sheets via a Chemical Method. Graphene 2014, 3, 7-13. [CrossRef]

35. Hutchison, R. Meteorites: A Petrologic, Chemical and Isotopic Synthesis; Cambridge University Press: Cambridge, UK, 2004.

36. Weisberg, M.K.; McCoy, T.J.; Krot, A.N. Systematics and Evaluation of Meteorite Classification. In Meteorites and the Early Solar System II; Lauretta, D.S., McSween, H.Y., Jr., Eds.; The University of Arizona Press: Tucson, AZ, USA, 2006 ; p. 34. 